\title{
P303: Safety of intravenous samples and risk management of infectious waste: the case of Mali
}

\author{
AM Traoré*, M Fomba, T Cissé, S Yehia, B Diarra, DS Ouloguem, H Cissé, DK Minta \\ From 2nd International Conference on Prevention and Infection Control (ICPIC 2013) \\ Geneva, Switzerland. 25-28 June 2013
}

\section{Introduction}

We conducted a one-day survey in a teaching hospital, two district centers, a community health center and military dispensary in Bamako in February 2012, as part of a multicenter GERES study.

\section{Objectives}

We aimed to determine the materials used in intravenous (IV) blood collection to clarify the availability of safety equipment and describe the measure to eliminate infectious waste.

\section{Methods}

Safety equipment for collection of IV blood samples were available in any center. The blood was drawn by syringes + needles and the equipment for collect blood was chosen by different people on the center. Funding was provided by the health department or the patient.

\section{Results}

A policy for waste management existed in every site but only 3 sites out of 5 had a written procedure, generally not distributed in all services. Containers for waste recovery were not specific (collector card, plastic security bin bag and a recycled bottle of bleach). Cardboard boxes were available for free. Two centers conducted soaking in bleach before handling. Four centers of five or had a dedicated staff trained in waste disposal. The cremation was carried out in three sites out of 5 . Other centers sent their waste to the health service district of Bamako.

\section{Conclusion}

Unavailability of safety equipment contributes to the exposure of personnel to blood exposure. We must strengthen

Service of Infectious Diseases, University Hospital of Point G, Bamako, Mali the technical platform and the system improves sorting and waste management.

\section{Disclosure of interest}

None declared.

Published: 20 June 2013

\section{doi:10.1186/2047-2994-2-S1-P303}

Cite this article as: Traoré et al:: P303: Safety of intravenous samples and risk management of infectious waste: the case of Mali. Antimicrobial Resistance and Infection Control 2013 2(Suppl 1):P303.

Submit your next manuscript to BioMed Central and take full advantage of:

- Convenient online submission

- Thorough peer review

- No space constraints or color figure charges

- Immediate publication on acceptance

- Inclusion in PubMed, CAS, Scopus and Google Scholar

- Research which is freely available for redistribution

Submit your manuscript at www.biomedcentral.com/submit 